\title{
Different Sources of Irrigation Water Affect Heavy Metals Accumulation in Soils and Subsequently on Physiological Determinants and Physico-Chemical Properties of Guava Fruits
}

\section{Sajjad Hussain ( $\sim$ sajjad.hussain@bzu.edu.pk)}

Bahauddin Zakariya University Faculty of Agriculture Science and Technology https://orcid.org/00000002-7143-2754

\section{Ahmad Hassan}

Bahauddin Zakariya University Faculty of Agriculture Science and Technology

Pakiza Arshad

Bahauddin Zakariya University Faculty of Agriculture Science and Technology Muhammad Akbar Anjum

Bahauddin Zakariya University Faculty of Agriculture Science and Technology

\section{Research Article}

Keywords: Psidium guajava, photosynthesis, wastewater, canal water, fruit analysis

Posted Date: June 1st, 2021

DOI: https://doi.org/10.21203/rs.3.rs-498294/v1

License: (c) (1) This work is licensed under a Creative Commons Attribution 4.0 International License. Read Full License 


\section{Abstract}

Guava is a highly nutritious fruit and widely grown in tropical and sub-tropical regions of the world. Guava orchards are frequently irrigated with contaminated water in different regions of the world. In the present study, fruits of two guava cultivars, i.e., Gola and Surahi were collected from orchards grown in peri-urban areas of Multan, Pakistan, which were irrigated with different sources of irrigation i.e., canal water, tubewell water and sewage water. The soil (at four different layers), water, and fruit (at harvesting) samples were collected from the orchards for their physical, chemical, and heavy metals analysis. The results revealed that sewage water contained more amount of copper, zinc and nickel as compared to tubewell and canal water. The soil irrigated with sewage water also contained the highest copper, nickel and zinc contents, while tubewell water irrigated soils contained the lowest copper, nickel and zinc contents. As regards different soil layers, the top soil layer $(0-15 \mathrm{~cm})$ contained the maximum copper, nickel and zinc contents. In contrast, the minimum copper, nickel and zinc contents were estimated in the lower most soil layer $(46-60 \mathrm{~cm})$. The different physiological parameters of guava leaves i.e., photosynthesis $\left(A_{\text {net }}\right)$, stomatal conductance $(\mathrm{gs})$, transpiration $(E)$, leaf chlorophyll fluorescence in light $\left(\mathrm{Fv}^{\prime} / \mathrm{Fm}^{\prime}\right)$ and in dark-acclimated (Fv/Fm) and non-photochemical quenching in dark-acclimated (NPQ) were decreased with sewage water irrigation. Further, the sources of irrigation water significantly altered the different physical and chemical properties of the fruits. It is concluded that sewage water improved the physico-chemical properties of fruits but these also had high amounts of different heavy metals. Further, the soil irrigated with sewage water also had high contents of different heavy metals.

\section{Highlights}

1. Different physiological attributes negatively affected by sewage water application

2. Guava fruit quality was improved in sewage water irrigation

3. High heavy metals contents were detected in sewage water irrigation orchards

4. Low heavy metals contents were observed in tubewell and canal irrigated orchards

5. Copper and Nickel were high in sewage irrigated orchards

\section{Introduction}

Generally, fruits and vegetables can replenish humans with an adequate amount of minerals and vitamins and are recommended by health organizations as an essential part of daily food intake. Fruits provide not only essential components of the human's diet but also other bioactive compounds such as natural antioxidants (Nicoli et al. 1999). However, agricultural commodities grown in suboptimal conditions or with substandard inputs can malnourish human with toxic quantities of these minerals. Trace minerals like copper $(\mathrm{Cu})$, zinc $(\mathrm{Zn})$, iron $(\mathrm{Fe})$ and manganese $(\mathrm{Mn})$ are necessary for normal body functions in all living organisms. However, higher human body levels of $\mathrm{Cu}, \mathrm{Zn}, \mathrm{Mn}$ and Fe or even lower levels of Arsenic (As), chromium ( $\mathrm{Cr}$ ), cadmium ( $\mathrm{Cd})$, nickel $(\mathrm{Ni})$ and lead $(\mathrm{Pb})$ can cause illness, ageing and genetic defects (Wargovich 2000; Gaur et al. 2004 and Wilson 2011). The excess of heavy metals accumulation in the human body causes severe systematic health harms (Alloway and Ayres 1997). 
Intake of excessive levels of toxic metals causes gastrointestinal, pancreas and urinary bladder cancer. $\mathrm{Cr}$ in high concentrations causes skin rashes, stomach upset and ulcer, respiratory problems, weakened immune systems, kidney and liver damage, alteration of genetic material and lungs cancer (Avena 1979). The concentration of $\mathrm{Pb}$ if found in maximum limits affects the nervous system, bones, liver, pancreas, teeth, gums and blood function (Abbas et al. 2010). The high concentration of Cd may cause severe tubular growth, kidney damage, cancer, diarrhea and incurable vomiting (Abbas et al. 2010). Ni toxicity causes lungs and blood cancer (Agarwal 2002). Increased level of copper in food can cause hepatic and kidney damage, hemolytic anemia and methemoglobinemia (Chugh et al. 1975). Even high nitrate $\left(\mathrm{NO}_{3}{ }^{-}\right)$ accumulation in plants is also harmful to humans, particularly to children (Ikemoto et al. 2002).

Developing countries like Pakistan is facing different environmental challenges because of the increase in urbanization. Growing population not only catalyzes the growth of cities, industry and transportation, it also disturbs the ecosystems, especially in peri-urban areas where major sources of contamination are air pollution, untreated wastewater and city and industry drains flushing into canals or rivers. As costeffective mass production of food is necessary to meet the demands of the growing economy and population, cheaply available untreated wastewater and canal water are frequently used for irrigation. Besides, fertilizers containing As and $\mathrm{Cd}$ as an enrichment have added to the soil contamination. In Pakistan, polluted water is used for drinking and irrigation purposes because of shortage of water. Approximately $80 \%$ of the diseases were due to unsafe drinking water in Pakistan and Azad and Jammu Kashmir (Javaid et al. 2008).

For the production of quality fruits, irrigation and fertilizer application have significant effects. Irrigation in arid and semi-arid conditions is required in a regular and adequate amount for commercial production of fruit crops. The need is usually met through canal, tube well, and sewage wastewater. The use of wastewater is an economical option but risky as it is loaded with salts, toxic metals and disease-causing microorganisms. Many farmers are irrigating their crops with sewage or such polluted water. Agricultural commodities are contaminated with heavy metals and causing several human health hazards. A major cause of heavy metal accumulation in soils near urban areas is irrigation with sewage water (Singh et al. 2004; Sharma et al. 2006, 2007). Moreover, fruits and vegetables were also polluted with the uncontrolled application of different fertilizers and other agrochemicals (Oliver 1997).

Soil fertility status is enhanced because of heavy metals content. However, the excess of heavy metals may cause toxicity (Alloway and Ayres 1997). Sewage sludge production is increasing worldwide in recent years and may perhaps increase with time (Pathak et al. 2009). The decomposition of sewage sludge resulting in heavy metals accumulation in soil (Ozores-hampton et al. 2005). The uncontrolled application of sewage water, chemical fertilizers, insecticides and weedicides in fruit orchards are resulting in undesirable accumulation of different heavy metals (Ang and $\mathrm{Ng} 2000$ ). The highest accumulation of heavy metals was recorded in urban areas of orchards because of irrigated water is mostly contaminated (Farooq et al. 2008). Several methods were adopted for the treatment of wastewater treatment i.e. coagulation, filtration, ion exchange and adsorption (Priya et al. 2009). Further, food authorities were working on the control of sewage water applications to crops. 
Guava (Psidium guajava L.) belongs to Myrtaceae family and is successfully cultivated in tropical and sub-tropical regions of the world (Gupta et al. 2011). It is a highly nutritious fruit crop after mango and citrus because of different vitamins (Mehmood et al. 2018). Guava is commercially cultivated in the Sindh and Punjab provinces of Pakistan with excellent fruit quality (Menzel et al. 1985). Guava is a rich source of vitamins i.e., A, B, C \& K, minerals, different sugars, oxalic acid and lactic acid. Further, higher antioxidants properties were also recorded in guava fruit crops (Gull et al. 2012). However, the use of sewage water for irrigation purposes is widespread in guava orchards. Fruits orchard irrigated with sewage water may accumulate high amount of heavy metals in edible parts of fruit trees. Little research work on the application of sewage water is available in different fruit trees. In a view, concentrations of these metals in tree fruits are very low even when grown on contaminated soils. Othman and Mbogo (2009) studied seven heavy metals (Al, Cd, Cu, Fe, Mn, Pb and $\mathrm{Zn}$ ) in two cultivars of mango grown in Eastern Tanzania. Their results showed very low concentrations of these metals that indicated insignificant pollution of the fruits. Similarly, in another survey, the daily intakes of $\mathrm{Pb}, \mathrm{Cd}, \mathrm{Cu}$ and $\mathrm{Zn}$ through fruits and vegetables in Egypt were found to be below the recommended tolerable levels proposed by FAO/WHO (Radwan and Salama 2006). In contrast view, the metal contents of some orchard soils may be high enough to cause adverse effects in people, plants and the environment as higher concentrations of these metals were found in the fruits of Pakistan (Zahoor and Zahoor 2003) than recommended by WHO (Akhtar et al. 2010). Plant species vary in preference of various heavy metals uptake (Wolnik et al.1983) such as mango accumulates a higher concentration of $\mathrm{Hg}$ than papaya and guava. Similarly, guava has a greater Pb content than mango and papaya (Ang and $\mathrm{Ng} 2000$ ) irrespective of planting sites.

Therefore, in the current study, we determine the effect of different sources of irrigation water i.e., canal, tubewell and sewage on different heavy metals accumulation such as copper, nickel, zinc and cadmium in soil. Moreover, the effects of accumulation of these heavy metals in soil on physiological attributes of leaves and physico-chemical properties of the fruit of two guava cultivars were studied.

\section{Materials And Methods \\ 2.1. Plant materials}

The experiment was conducted in the peri-urban areas of Multan, Pakistan. The preliminary survey was conducted to identify the different orchards irrigated with different sources of irrigation water, i.e. canal water, tubewell water and sewage water. The fruits of two guava cultivars, i.e. Gola and Surahi were collected at physical maturity from these orchards for further physical and biochemical analysis. These physical and biochemical analysis of fruits were conducted in the Postgraduate lab of the Department of Horticulture. The study was designed according to randomized complete block design (RCBD) with two factors (cultivar and irrigation sources) and three replications.

\subsection{Heavy metals estimation in soil}


For heavy metal estimation, soil samples were collected from guava orchards irrigated with canal water, tubewell water and sewage water at four different depths i.e. $\mathrm{S} 1=0-15 \mathrm{~cm}, 16-30 \mathrm{~cm}, 31-45 \mathrm{~cm}$ and 46-60 $\mathrm{cm}$ by using an auger apparatus. All samples were brought in the laboratory and dried at room temperature without sunlight for three days. After that, the samples were dried in the oven for two days at $70^{\circ} \mathrm{C}$. After drying, soil samples were saved for further analysis. Heavy metals estimation in soil samples was made through diethylene triamine penta acetic acid (DTPA). For analysis, $20 \mathrm{~g}$ soil sample was added in $40 \mathrm{~mL}$ of DTPA $(7.3 \mathrm{pH})$ and reading was noted through an Atomic absorption spectrophotometer (Thermo Scientific 3000 series, USA). The reaction solution contained $1.96 \mathrm{~g}$ DPTA, $1.47 \mathrm{~g}$ calcium chloride and $12.65 \mathrm{~mL}$ tri-ethanol amine).

\subsection{Heavy metals estimation in water}

Water samples were collected from the above mentioned irrigation sources. Water samples were then filtered with Whatman filter paper No. 2. Atomic absorption spectrophotometer (Thermo Scientific 3000 series, USA) was used for the estimation of heavy metal in water samples.

\subsection{Heavy metals estimation in fruits}

The fruits were collected from the orchards and dried at $65^{\circ} \mathrm{C}$ in an oven until their weight became constant. The dried fruits were then ground into a fine powder. Then, $0.5 \mathrm{~g}$ dried fruit samples were added in nitric acid and perchloric acid with the ratio of 3:1 and kept for overnight. After that, samples were kept at $200^{\circ} \mathrm{C}$ until colourless solutions obtained. The samples were then diluted by adding $25 \mathrm{~mL}$ of distilled water (Farooq et al. 2008). After digestion $\mathrm{Cu}, \mathrm{Zn}, \mathrm{Cd}$, and Ni were determined using an Atomic absorption spectrophotometer (Thermo Scientific 3000 series, USA).

\subsection{Physiological attributes of plant leaves}

Different leaf physiological parameters, $A_{\text {net }}$, gs and $E$ were measured with an infrared gas analyzer (LCiSD, BioScientific Ltd. UK). The Fv'/Fm', Fv/Fm and NPQ in leaves were measured with a chlorophyll fluorometer (FluorPen FP-100, Photon Systems Instruments, Czech Republic). Different photosynthetic variables were measured between $9 \mathrm{am}-11 \mathrm{am}$. In contrast, for dark-acclimated photosynthetic variables leaves were covered for one hour before taking the measurements.

\subsection{Fruit physical attributes}

The physical parameters of fruits, i.e., fresh and dry fruit weights were measured by using a digital weighing balance. The fruit diameter (equatorial and polar) was determined by using a digital vernier calliper.

Sensory evaluation was carried out using a hedonic scale included 9 points as described by Anjum et al. (2020) with a panel consist of 10 people. The hedonic scale was as very excellent (9), excellent (8), very good (7), good (6), fair (5), slightly dislike (4), moderately dislike (3), rough (2), very rough (1). The shelf life of fruits was also observed through eating quality and suitable saleable aspects.

\subsection{Fruit biochemical attributes}


The fresh fruit pulp was used for the determination of different biochemical parameters. The total soluble solids (TSS) was measured using hand refractometer, $\mathrm{pH}$ and electrical conductivity (EC) were estimated through $\mathrm{pH}$ and EC meters, titratable acidity (TA) and vitamin $\mathrm{C}$ content were measured using a titration method (Ruck, 1963). Total phenolic content (TPC), antioxidant activity (AA) and antioxidant capacity (AC) were measured according to Anjum et al. (2018). Total carotenoid content was measured according to a method of Lee and Castle (2001) with little modifications. The absorbance of the sample for carotenoid was measured using a spectrophotometer (UV-1900 UV/Vis) at wavelength $450 \mathrm{~nm}$. Fresh fruit pulp was used for determining total flavonoids in guava fruits according to a method as described earlier (Kaushik et al. 2013).

\subsection{Statistical analysis}

The analysis of variance was performed by using Statistix 8.1 (Tallahassee Florida, USA). At a 5\% probability level, the least significant difference test was used for the comparison of means (Gomez and Gomez 1984).

\section{Results}

\subsection{Gas exchange and chlorophyll fluorescence}

Different physiological parameters were significantly affected by different sources of irrigation water. The $A_{\text {net }}$ gs and $E$ in leaves of both guava cultivars were high in tube well water irrigated orchards compared to sewage and canal water irrigated ones and the difference was significant. The low values of physiological attributes, as mentioned above, were observed in sewage water irrigated orchards (Fig. 1).

The Fv/Fm and Fv'/Fm' were decreased in leaves of both guava cultivars irrigated with the sewage water. In contrast, the NPQ was increased in leaves of both guava cultivars irrigated with the sewage water. The $\mathrm{Fv} / \mathrm{Fm}$ and $\mathrm{Fv}^{\prime} / \mathrm{Fm}^{\prime}$ were high in tubewell and canal water irrigated orchards. In contrast, the NPQ was low in tubewell and canal water irrigated orchards (Fig. 1).

\subsection{Heavy metals content in water, soil and fruit}

The different sources of irrigation water i.e. canal water, tubewell water and sewage water contained the significantly different amount of heavy metals (Table 1). The sewage water contained the highest amounts of different heavy metals i.e. $\mathrm{Cu}(0.08 \mathrm{ppm}), \mathrm{Ni}(0.40 \mathrm{ppm})$ and $\mathrm{Zn}(0.55 \mathrm{ppm})$, while the tubewell water contained the lowest amounts i.e. $\mathrm{Cu}(0.00 \mathrm{ppm}), \mathrm{Ni}(0.07 \mathrm{ppm})$ and $\mathrm{Zn}$ content $(0.16$ ppm). 
Table 1

Availability of heavy metals in irrigation water applied to the guava orchards

\begin{tabular}{|lllll|}
\hline Water sources & Copper (ppm) & Nickel (ppm) & Zinc (ppm) & Cadmium (ppm) \\
\hline Canal water & $0.00 \mathrm{~b}$ & $0.31 \mathrm{a}$ & $0.34 \mathrm{~b}$ & $\mathrm{ND}$ \\
\hline Tubewell water & $0.00 \mathrm{~b}$ & $0.07 \mathrm{~b}$ & $0.16 \mathrm{c}$ & $\mathrm{ND}$ \\
\hline Sewage water & $0.08 \mathrm{a}$ & $0.40 \mathrm{a}$ & $0.55 \mathrm{a}$ & $\mathrm{ND}$ \\
\hline * Means sharing similar letter(s) in a group are statistically non-significant at $p=0.05$ (LSD test) \\
\hline
\end{tabular}

Concerning the soil, the heavy metals accumulation was significantly affected by different sources of irrigation. The results showed that soils irrigated with sewage water accumulated the highest amounts of different heavy metals i.e. $\mathrm{Cu}(7.79 \mathrm{ppm}), \mathrm{Ni}(59.18 \mathrm{ppm})$ and $\mathrm{Zn}(32.21 \mathrm{ppm})$. In contrast, tubewell water irrigated soils accumulated the lowest i.e. Cu (2.39 ppm), Ni (29.13 ppm) and Zn (18.92 ppm). Further, It was observed that heavy metal accumulation was decreased with an increase in the depth of soil. The more heavy metal accumulation was observed in the upper soil layer $(0-15 \mathrm{~cm})$ compared to the lower most soil layer $(46-60 \mathrm{~cm})$ (Table 2$)$. 
Table 2

Impact of different irrigation water sources on accumulation of different heavy metals in different layers of soils of guava orchards

\begin{tabular}{|c|c|c|c|c|c|c|}
\hline \multirow[t]{2}{*}{ Heavy metals } & \multirow{2}{*}{$\begin{array}{l}\text { Irrigation } \\
\text { sources }\end{array}$} & \multicolumn{4}{|c|}{ Soil layers / depth } & \multirow[t]{2}{*}{ Mean } \\
\hline & & $0-15 \mathrm{~cm}$ & $16-30 \mathrm{~cm}$ & $31-45 \mathrm{~cm}$ & $46-60 \mathrm{~cm}$ & \\
\hline \multirow[t]{4}{*}{ Copper (ppm) } & Canal water & $3.61 \mathrm{de}$ & 3.00 def & 2.25 ef & 0.70 ef & $2.39 \mathrm{c}$ \\
\hline & Tubewell water & $8.48 \mathrm{bc}$ & $5.56 \mathrm{~cd}$ & 1.46 ef & 0.73 ef & $4.06 \mathrm{~b}$ \\
\hline & Sewage water & $16.75 \mathrm{a}$ & $11.11 \mathrm{~b}$ & 3.15 def & $0.17 f$ & 7.79 a \\
\hline & Mean & $9.61 \mathrm{a}$ & $6.55 \mathrm{~b}$ & $2.28 \mathrm{c}$ & $0.53 \mathrm{c}$ & \\
\hline \multirow[t]{4}{*}{ Nickel (ppm) } & Canal water & 53.79 a & 46.79 a & $41.85 \mathrm{a}$ & 32.62 a & $43.76 \mathrm{~b}$ \\
\hline & Tubewell water & $45.11 \mathrm{a}$ & $30.85 a$ & $26.94 \mathrm{a}$ & $13.65 \mathrm{a}$ & $29.13 \mathrm{c}$ \\
\hline & Sewage water & 70.07 a & 61.73 a & $58.12 \mathrm{a}$ & 46.79 a & 59.18 a \\
\hline & Mean & 56.32 a & $46.46 \mathrm{~b}$ & $42.30 \mathrm{~b}$ & $31.02 \mathrm{c}$ & \\
\hline \multirow[t]{4}{*}{ Zinc (ppm) } & Canal water & $32.30 \mathrm{c}$ & $29.69 \mathrm{c}$ & $21.42 \mathrm{de}$ & $17.06 \mathrm{fg}$ & $25.12 b$ \\
\hline & Tubewell water & $23.90 \mathrm{~d}$ & 20.19 e & $16.73 \mathrm{~g}$ & $14.89 \mathrm{~g}$ & $18.92 \mathrm{c}$ \\
\hline & Sewage water & 40.87 a & $36.80 \mathrm{~b}$ & $31.42 \mathrm{c}$ & 19.77 ef & $32.21 \mathrm{a}$ \\
\hline & Mean & $32.35 \mathrm{a}$ & $28.89 \mathrm{~b}$ & $23.19 \mathrm{c}$ & $17.24 \mathrm{~d}$ & \\
\hline \multirow{4}{*}{$\begin{array}{l}\text { Cadmium } \\
\text { (ppm) }\end{array}$} & Canal water & ND & ND & ND & ND & ND \\
\hline & Tubewell water & ND & ND & ND & ND & ND \\
\hline & Sewage water & ND & ND & ND & ND & ND \\
\hline & Mean & ND & ND & ND & ND & ND \\
\hline
\end{tabular}

The heavy metals accumulation in fruits was significantly affected by the different sources of irrigation water. The fruits irrigated with sewage water accumulated the highest amounts of $\mathrm{Cu}(38.30 \mathrm{ppm}), \mathrm{Ni}$ $(19.26 \mathrm{ppm})$ and $\mathrm{Zn}(44.08 \mathrm{ppm})$. In contrast, the fruits irrigated with tubewell water accumulated the lowest amounts of $\mathrm{Cu}(14.26 \mathrm{ppm}), \mathrm{Ni}(1.17 \mathrm{ppm})$ and $\mathrm{Zn}(9.41 \mathrm{ppm})$ (Table 3). Moreover, the heavy metal accumulation was not affected by the cultivars studied and the difference was non-significant. The cadmium was not detected in, all different sources of irrigation water, all layers of soils and fruits of both cultivars. 
Table 3

Effect of various irrigation water sources on accumulation of heavy metals in fruits of guava

\begin{tabular}{|c|c|c|c|c|}
\hline \multirow[t]{2}{*}{ Heavy metals } & \multirow[t]{2}{*}{ Irrigation sources } & \multicolumn{2}{|l|}{ Cultivars } & \multirow[t]{2}{*}{ Mean } \\
\hline & & Gola & Surahi & \\
\hline \multirow[t]{4}{*}{ Copper (ppm) } & Canal water & $18.74 \mathrm{c}$ & $23.95 b$ & $21.34 \mathrm{~b}$ \\
\hline & Tubewell water & $15.91 \mathrm{~cd}$ & $12.61 \mathrm{~d}$ & $14.26 \mathrm{c}$ \\
\hline & Sewage water & $37.15 \mathrm{a}$ & $39.44 \mathrm{a}$ & $38.30 \mathrm{a}$ \\
\hline & Mean & $23.93 \mathrm{a}$ & $25.33 \mathrm{a}$ & \\
\hline \multirow[t]{4}{*}{ Nickel (ppm) } & Canal water & $14.61 \mathrm{a}$ & 10.81 a & $12.71 \mathrm{~b}$ \\
\hline & Tubewell water & $1.17 \mathrm{a}$ & $1.17 \mathrm{a}$ & $1.17 \mathrm{c}$ \\
\hline & Sewage water & 20.61 a & $17.91 \mathrm{a}$ & $19.26 \mathrm{a}$ \\
\hline & Mean & $12.13 \mathrm{a}$ & $9.96 \mathrm{a}$ & \\
\hline \multirow[t]{4}{*}{ Zinc (ppm) } & Canal water & 28.87 a & $33.84 \mathrm{a}$ & $31.35 b$ \\
\hline & Tubewell water & $8.26 \mathrm{a}$ & $10.57 \mathrm{a}$ & $9.41 \mathrm{c}$ \\
\hline & Sewage water & $40.71 \mathrm{a}$ & $47.44 \mathrm{a}$ & $44.08 \mathrm{a}$ \\
\hline & Mean & $25.95 a$ & 30.61 a & \\
\hline \multirow[t]{4}{*}{ Cadmium (ppm) } & Canal water & $C D$ & CD & $C D$ \\
\hline & Tubewell water & $C D$ & $C D$ & $C D$ \\
\hline & Sewage water & $C D$ & $C D$ & $C D$ \\
\hline & Mean & $C D$ & CD & CD \\
\hline
\end{tabular}

Different physical properties of fruits like fresh and dry fruit weights and polar and equatorial diameters were not significantly affected by the different sources of irrigation water. However, the value of different physical properties was a bit high in fruits irrigated with sewage water (Table 4). For different organoleptic properties, flavor, eating quality and texture were significantly better in fruits irrigated with sewage water when compared to other sources of irrigation. Further, the aroma was significantly better in fruit irrigated with canal water and shelf life was significantly better in fruits irrigated with tubewell water (Table 5). 
Table 4

Effect of various sources of irrigation water on physical traits of fruits of guava cultivars

\begin{tabular}{|c|c|c|c|c|}
\hline \multirow[t]{2}{*}{ Heavy metals } & \multirow[t]{2}{*}{ Irrigation sources } & \multicolumn{2}{|l|}{ Cultivars } & \multirow[t]{2}{*}{ Mean } \\
\hline & & Gola & Surahi & \\
\hline \multirow[t]{4}{*}{ Fresh fruit weight $(\mathrm{g})$} & Canal water & $124.23 \mathrm{a}$ & $120.49 a$ & $122.36 \mathrm{a}$ \\
\hline & Tubewell water & $123.89 \mathrm{a}$ & $120.56 \mathrm{a}$ & $122.22 \mathrm{a}$ \\
\hline & Sewage water & $125.02 \mathrm{a}$ & $120.72 \mathrm{a}$ & 122.87 a \\
\hline & Mean & $124.38 \mathrm{a}$ & 120.59 a & \\
\hline \multirow[t]{4}{*}{ Dry fruit weight (g) } & Canal water & $32.42 \mathrm{a}$ & $26.47 \mathrm{a}$ & $29.45 \mathrm{a}$ \\
\hline & Tubewell water & $32.53 \mathrm{a}$ & $26.37 \mathrm{a}$ & $29.45 \mathrm{a}$ \\
\hline & Sewage water & $32.94 \mathrm{a}$ & $35.43 \mathrm{a}$ & 34.18 a \\
\hline & Mean & $32.63 \mathrm{a}$ & 29.42 a & \\
\hline \multirow[t]{4}{*}{ Polar diameter (mm) } & Canal water & 59.22 a & $66.53 \mathrm{a}$ & $62.87 a$ \\
\hline & Tubewell water & 59.83 a & $67.80 \mathrm{a}$ & $63.81 \mathrm{a}$ \\
\hline & Sewage water & $60.61 \mathrm{a}$ & 70.16 a & $65.38 \mathrm{a}$ \\
\hline & Mean & $59.88 \mathrm{~b}$ & $68.16 \mathrm{a}$ & \\
\hline \multirow[t]{4}{*}{ Equatorial diameter (mm) } & Canal water & 59.88 a & $57.74 \mathrm{a}$ & 58.81 a \\
\hline & Tubewell water & $60.76 \mathrm{a}$ & $57.74 \mathrm{a}$ & $59.25 \mathrm{a}$ \\
\hline & Sewage water & $61.54 \mathrm{a}$ & 57.73 a & 59.63 a \\
\hline & Mean & $60.73 a$ & $57.74 \mathrm{~b}$ & \\
\hline
\end{tabular}


Table 5

Effect of various sources of irrigation water on organoleptic properties of fruits of guava cultivars

\begin{tabular}{|c|c|c|c|c|}
\hline \multirow[t]{2}{*}{ Heavy metals } & \multirow[t]{2}{*}{ Irrigation sources } & \multicolumn{2}{|c|}{ Cultivars } & \multirow[t]{2}{*}{ Mean } \\
\hline & & Gola & Surahi & \\
\hline \multirow[t]{4}{*}{ Aroma } & Canal water & $8.30 \mathrm{a}$ & $7.80 \mathrm{a}$ & $8.05 \mathrm{a}$ \\
\hline & Tubewell water & $7.66 \mathrm{a}$ & $7.80 \mathrm{a}$ & $7.73 a b$ \\
\hline & Sewage water & $7.33 \mathrm{a}$ & $7.66 \mathrm{a}$ & $7.50 \mathrm{~b}$ \\
\hline & Mean & $7.76 \mathrm{a}$ & $7.75 \mathrm{a}$ & \\
\hline \multirow[t]{4}{*}{ Flavor } & Canal water & $7.30 \mathrm{~d}$ & $8.00 \mathrm{abc}$ & $7.65 \mathrm{~b}$ \\
\hline & Tubewell water & $7.90 \mathrm{bc}$ & $7.80 \mathrm{c}$ & $7.85 \mathrm{~b}$ \\
\hline & Sewage water & $8.46 \mathrm{a}$ & $8.33 a b$ & $8.40 \mathrm{a}$ \\
\hline & Mean & $7.88 \mathrm{a}$ & $8.04 \mathrm{a}$ & \\
\hline \multirow[t]{4}{*}{ Eating quality } & Canal water & $7.30 \mathrm{c}$ & $8.20 \mathrm{~b}$ & $7.75 \mathrm{c}$ \\
\hline & Tubewell water & $7.90 \mathrm{~b}$ & $8.23 \mathrm{~b}$ & $8.06 \mathrm{~b}$ \\
\hline & Sewage water & $8.66 \mathrm{a}$ & $8.66 \mathrm{a}$ & $8.66 \mathrm{a}$ \\
\hline & Mean & $7.95 \mathrm{~b}$ & $8.36 \mathrm{a}$ & \\
\hline \multirow[t]{4}{*}{ Texture } & Canal water & $7.90 \mathrm{a}$ & $7.80 \mathrm{a}$ & $7.85 \mathrm{a}$ \\
\hline & Tubewell water & $7.80 \mathrm{a}$ & $7.80 \mathrm{a}$ & $7.80 \mathrm{a}$ \\
\hline & Sewage water & $8.13 \mathrm{a}$ & $8.23 \mathrm{a}$ & $8.18 \mathrm{a}$ \\
\hline & Mean & $7.94 a$ & $7.94 a$ & \\
\hline \multirow[t]{4}{*}{ Shelf life } & Canal water & $9.00 \mathrm{a}$ & $9.00 \mathrm{a}$ & $9.00 \mathrm{c}$ \\
\hline & Tubewell water & $10.00 \mathrm{a}$ & $10.00 \mathrm{a}$ & $10.00 \mathrm{a}$ \\
\hline & Sewage water & $9.66 \mathrm{a}$ & $9.00 \mathrm{a}$ & $9.33 \mathrm{~b}$ \\
\hline & Mean & $9.55 \mathrm{a}$ & $9.33 \mathrm{a}$ & \\
\hline
\end{tabular}

3.4. Effect of heavy metals on biochemical properties of guava fruits

The different biochemical properties of fruits were significantly affected by the different sources of irrigation water. The $\mathrm{pH}$ (3.78), EC (3.63), titratable acidity (1.17\%), ascorbic acid content $(80.58 \mathrm{mg} / 100$ $\mathrm{mL})$, total phenolics $(511.32 \mu \mathrm{g} \mathrm{GAE} / \mathrm{mL})$, antioxidant activity $(98.20 \%)$ and total flavonoids (274.01 QE/ 
$100 \mathrm{~g}$ ) were high in fruits irrigated with sewage water (Table 6). In contrast, the values of the abovementioned attributes were lower in fruits irrigated with tubewell water. The values of TSS (11.00 खBrix) and total carotenoids $(6.67 \mu \mathrm{g} / \mathrm{mL})$ were higher in fruits irrigated with canal water and lower in fruits irrigated with tubewell water. 
Table 6

Effect of various sources of irrigation water on biochemical properties of fruits of guava cultivars

\begin{tabular}{|c|c|c|c|c|}
\hline \multirow[t]{2}{*}{ Heavy metals } & \multirow[t]{2}{*}{ Irrigation sources } & \multicolumn{2}{|l|}{ Cultivars } & \multirow[t]{2}{*}{ Mean } \\
\hline & & Gola & Surahi & \\
\hline \multirow[t]{4}{*}{ TSS (『Brix) } & Canal water & $11.33 \mathrm{a}$ & 10.66 a & $11.00 \mathrm{a}$ \\
\hline & Tubewell water & $10.33 \mathrm{a}$ & 9.33 a & $9.83 \mathrm{~b}$ \\
\hline & Sewage water & $10.66 \mathrm{a}$ & $10.33 \mathrm{a}$ & $10.50 \mathrm{ab}$ \\
\hline & Mean & 10.77 a & $10.11 \mathrm{~b}$ & \\
\hline \multirow[t]{4}{*}{ Potential acidity $(\mathrm{pH})$} & Canal water & $3.66 \mathrm{a}$ & $3.74 \mathrm{a}$ & $3.70 \mathrm{~b}$ \\
\hline & Tubewell water & $3.65 \mathrm{a}$ & $3.70 \mathrm{a}$ & $3.67 \mathrm{~b}$ \\
\hline & Sewage water & 3.77 a & 3.79 a & 3.78 a \\
\hline & Mean & $3.69 \mathrm{~b}$ & 3.74 a & \\
\hline \multirow[t]{4}{*}{ Electrical conductivity (EC) } & Canal water & $2.80 \mathrm{a}$ & $2.60 \mathrm{a}$ & $2.70 \mathrm{~b}$ \\
\hline & Tubewell water & $2.76 \mathrm{a}$ & $2.47 \mathrm{a}$ & $2.62 \mathrm{~b}$ \\
\hline & Sewage water & $3.82 \mathrm{a}$ & $3.45 a$ & $3.63 \mathrm{a}$ \\
\hline & Mean & $3.13 \mathrm{a}$ & $2.84 \mathrm{~b}$ & \\
\hline \multirow[t]{4}{*}{ Titratable acidity (\%) } & Canal water & $1.14 \mathrm{a}$ & 0.89 a & $1.02 \mathrm{~b}$ \\
\hline & Tubewell water & $0.89 a$ & $0.72 \mathrm{a}$ & $0.89 \mathrm{~b}$ \\
\hline & Sewage water & $1.40 \mathrm{a}$ & $0.93 a$ & 1.17 a \\
\hline & Mean & $1.20 \mathrm{a}$ & $0.85 b$ & \\
\hline \multirow[t]{4}{*}{ Ascorbic acid (mg/ 100 mL) } & Canal water & 84.20 a & $68.46 \mathrm{a}$ & 76.33 a \\
\hline & Tubewell water & $74.53 \mathrm{a}$ & $58.80 \mathrm{a}$ & $66.66 \mathrm{~b}$ \\
\hline & Sewage water & $89.06 \mathrm{a}$ & $72.10 \mathrm{a}$ & 80.58 a \\
\hline & Mean & 82.59 a & $66.45 \mathrm{~b}$ & \\
\hline \multirow[t]{4}{*}{ Total phenolics $(\mu \mathrm{g} \mathrm{GAE} / \mathrm{mL})$} & Canal water & $302.41 \mathrm{a}$ & 322.07 a & $312.24 \mathrm{~b}$ \\
\hline & Tubewell water & $292.36 \mathrm{a}$ & 315.25 a & $303.80 \mathrm{~b}$ \\
\hline & Sewage water & $508.77 a$ & 513.86 a & 511.32 a \\
\hline & Mean & $367.85 b$ & 383.73 a & \\
\hline Carotenoids $(\mu \mathrm{g} / \mathrm{mL})$ & Canal water & $6.67 \mathrm{a}$ & $6.67 \mathrm{a}$ & $6.67 a$ \\
\hline
\end{tabular}

* Means sharing similar letter(s) in a group are statistically non-significant at $p=0.05$ (LSD test) 


\begin{tabular}{|c|c|c|c|c|}
\hline & Tubewell water & $6.67 \mathrm{a}$ & $2.00 \mathrm{a}$ & $1.33 \mathrm{c}$ \\
\hline & Sewage water & $5.00 \mathrm{a}$ & $4.00 \mathrm{a}$ & $4.50 \mathrm{~b}$ \\
\hline & Mean & $2.11 \mathrm{a}$ & $2.22 \mathrm{a}$ & \\
\hline \multirow[t]{4}{*}{ Antioxidant activity (\%) } & Canal water & $97.13 b$ & $97.78 a b$ & $97.45 \mathrm{a}$ \\
\hline & Tubewell water & $94.67 \mathrm{c}$ & $92.71 \mathrm{~d}$ & $93.69 \mathrm{~b}$ \\
\hline & Sewage water & $97.83 a b$ & $98.56 \mathrm{a}$ & $98.20 \mathrm{a}$ \\
\hline & Mean & $96.54 \mathrm{a}$ & 96.35 a & \\
\hline \multirow[t]{4}{*}{ Total flavonoids (mg QE/ $100 \mathrm{~g}$ ) } & Canal water & $164.11 \mathrm{a}$ & 185.78 a & $174.95 \mathrm{~b}$ \\
\hline & Tubewell water & $157.92 \mathrm{a}$ & $164.11 \mathrm{a}$ & $161.02 b$ \\
\hline & Sewage water & $263.17 a$ & $284.84 \mathrm{a}$ & $274.01 a$ \\
\hline & Mean & $195.07 \mathrm{a}$ & $211.58 \mathrm{a}$ & \\
\hline
\end{tabular}

For cultivars, the high values of TSS (10.77 खBrix), EC (3.13), titratable acidity (1.20\%) and ascorbic acid content $(82.59 \mathrm{mg} / 100 \mathrm{~mL})$ were noted in fruits of Gola cultivar and low values of TSS (10.11 खBrix), EC (2.54), titratable acidity $(0.85 \%)$ and ascorbic acid content $(66.45 \mathrm{mg} / 100 \mathrm{~mL})$ were noted in Surahi cultivar. In contrast, the high values of $\mathrm{pH}(3.74)$ and totals phenolics ( $383.73 \mu \mathrm{g} \mathrm{GAE} / \mathrm{mL}$ ) were observed in fruits of Surahi and the low values of $\mathrm{pH}$ (3.69) and totals phenolics $(367.85 \mu \mathrm{g} \mathrm{GAE} / \mathrm{mL})$ were observed in Gola. The total carotenoids, antioxidant activity and total flavonoids were not significantly different between the two cultivars.

\section{Discussion}

The guava orchards in periphery of Multan city are mainly grown under sewage water. The orchards grown with sewage water showed the excess amount of heavy metals in soil and also the accumulation of heavy metals in fruits. Heavy metals are very much injurious to human health. In this study, we explored the physiological attributes of trees and fruit analysis and heavy metal detection of guava orchards irrigated with canal water, sewage water and tubewell water. The photosynthetic rate was strictly restricted by the presence of toxic metals in plants. These metals significantly affected the biosynthesis of chlorophyll, photochemical reactions and enzymes of the Calvin cycle (Chugh and Sawhney 1999). In our findings, the trees irrigated with sewage water showed the maximum amount of heavy metals, as a result, the guava plants showed a decrease in photosynthetic rate, transpiration rate, and stomatal conductance (Fig. 1). Our results are in line with the findings of previous researchers that photosynthetic variables in plants decreased when exposed to heavy metals concentrations (Bauman et al. 2009; Hattab et al. 2009; Ouyang et al. 2012). The accumulation of heavy metals in plants alters the chloroplast membrane and disturb the electron transport chain, more specifically PSII (Mysliwa-Kurdziel et al. 2002). 
In our findings, the plants exposed to sewage water showed less Fv/Fm and Fv'/Fm' than tubewell water and canal water, which depicts that decrease in these variables showed the stress. The decline in Fv/Fm and Fv'/Fm' of PSII indicates the photoinhibition caused by excess photon flux density when plants are exposed to environmental stress (Björkman and Demming 1987). Moreover, the increase in NPQ was observed in the plants irrigated with the sewage water. The increase in NPQ is mainly due to dissipation of damaging excess energy, which may also compete with photochemical quenching and reduce photosynthetic electron transport, as evidenced by the reduction in Fv'/Fm' (Chaves et al. 2009).

These days, with the growth of the global economy and changing climate, water and soil contamination by different heavy metal has increased, which results in deterioration of the global ecosystem. The different sources of irrigation water can have different levels of minerals and heavy metals content. The heavy metals increasingly pollute the agricultural soil through different sources of irrigation water; hence, heavy metal toxicity is inflowing into the food chain, which affects the food quality and safety for humans. Our results also suggested that heavy metals accumulation in soil were different with different sources of irrigation water. Sewage water contained the highest heavy metals content than tubewell and canal water. The high amounts of heavy metals in the orchards irrigated with the sewage water are due to presence of high amounts of heavy metals in the sewage water. The current study is under the conformity of earlier studies which showed that soils irrigated with wastewater contain the highest level of heavy metals contents (Al-Omron et al. 2012). Further, the decrease in heavy metals contents was observed with an increase in the depth of soil. The similar finding was observed that the heavy metal accumulation in soil decreased with the soil depth (Rahaman et al. 2016) due to their slow movement in the soil profile.

The tolerance towards heavy metal stresses varies from specie to specie, stages of growth, and plant parts (Souri et al. 2019). The performance of cultivars may vary because of different genetic makeups. The guava cultivars showed a differential mechanism regarding the absorbance of different heavy metals content. Cultivars showed differential behaviour under wastewater irrigation because of different genetic makeup (Lone et al. 2003; Arora et al. 2008). Sewage water contained different organic and inorganic nutrients, which are significantly involved in plant growth and good quality of fruits (Hassanein et al. 2013). The current study is under the agreement with the previous findings (Lone et al. 2003). The fruit cultivars showed differential concentrations on their biochemical attributes might be due to genetic diversity (Khalid et al. 2017). Sewage water improves the biochemical properties i.e., TSS, pH, potential acidity, vitamin $\mathrm{C}$, antioxidants of guava cultivars. Moreover, trees irrigated with sewage water have more heavy metal contents in soil and trees. The previous studies showed that the transfer factor of heavy metals in edible parts of fruits and vegetables were high under sewage water (Cui et al. 2004; Luo et al. 2011).

\section{Conclusion}

Guava is a highly nutritious fruit crop with higher minerals and vitamins. Wastewater use is going to increase with time. The use of sewage water is also affecting plant health by disturbing its physiological attributes, and increase accumulation of toxic metals in fruits, which poses many threats to human 
health. Sewage water irrigation improved the quality of guava cultivars, which seems to be attractive to the farmers. However, at the same time, sewage water contaminated the soils, leaves and fruits with heavy metals in comparison to canal and tubewell water. Zinc and cadmium were not detected in any water, soil, leaf and fruit samples in the studied areas. Copper and nickel were high in soils, leaves and fruits of sewage water irrigated orchards. Canal and tubewell water irrigated orchards accumulated low metals contents in soils, leaves and fruits.

\section{Declarations}

\section{Acknowledgement}

This work is part of the research project "Toxicological and biochemical studies on some selected fruits grown in peri-urban areas of Multan" sponsored by Higher Education Commission, Islamabad under the research grant \# HEC-NRPU 3744.

\section{Ethics approval and consent to participate}

Not applicable

\section{Consent for publication}

Not applicable

\section{Availability of data and materials}

The datasets used and/or analysed during the current study are available from the corresponding author on reasonable request.

\section{Competing interests}

The authors declare that they have no competing interests

\section{Funding}

This work is part of the research project "Toxicological and biochemical studies on some selected fruits grown in peri-urban areas of Multan" sponsored by Higher Education Commission, Islamabad under the research grant \# HEC-NRPU 3744.

\section{Authors' contributions}

$\mathrm{SH}$ analyzed and interpreted the data and was a major contributor in writing the manuscript. $\mathrm{AH}$ and PA performed the Experiment and collected the data. MAA design the experiment and contribute the manuscript writing. All authors read and approved the final manuscript." 


\section{References}

1. Abbas M, Parveen Z, lqbal M, Riazuddin M, Iqbal S, Ahmed M, Bhutto R (2010) Monitoring of toxic metals (Cadmium, Lead, Arsenic and Mercury) in vegetables of Sindh, Pakistan. Kathmandu Univ J Sci Engg Technol 6, 60- 65.

2. Agarwal SK (2002) Pollution Management. Vol. V: Heavy Metal Pollution. A.P.H. Publishing Company, New Dehli, pp. 145-163.

3. Akhtar S, Naz S, Sultan MT, Mahmood S, Nasir M, Ahmad A (2010) Physico-chemical attributes and heavy metal content of mangoes (Mangifera indica L.) cultivated under different regions of Pakistan. Pak J Bot 42, 2691-2702

4. Alloway BJ, Ayres DC (1997) Chemical principles of environmental pollution, second edition, Blackie academic and professional. Chapman and Hall, London, pp. 208-211.

5. Al-Omron AM, El-Maghraby SE, El-Eter AM, Al-Mohani H (2012) Long-term effect of irrigation with the treated sewage effluent on some soil properties of Al-Hassa Governorate, Saudi Arabia J Saudi Soc Agric Sci 11, 15-18.

6. Ang LH, Ng LT (2000) Trace element concentration in Mango (Mangifera indica L.), seedless guava (Psidium guajava L.) and papaya (Carica papaya L.) grown on agricultural and ex-mining lands of Bidor, Perak. Pertanika J Trop Agric Sci 23, 15-22.

7. Anjum MA, Haram A, Ahmad R, Bashir MA (2020) Physico-chemical attributes of fresh and dried Indian jujube (Zizyphus mauritiana) fruits. Pak J Agric Sci 57, 165-176.

8. Anjum MA, Rauf A, Bashir MA, Ahmad R (2018) The evaluation of biodiversity in some indigenous Indian jujube (Zizyphus mauritiana) germplasm through physico-chemical analysis. Acta Sci Pol Hortorum Cultus 17, 9-52.

9. Arora M, Kiran B, Rani S, Rani A, Kaur B, Mittal N (2008) Heavy metal accumulation in vegetables irrigated with water from different sources. Food Chem 111, 811-815.

10. Avena JM (1979) Metallic Poisons. In: Charles, C.T. (ed.). Poisoning (4 ${ }^{\text {th }}$ Ed.). Springfield, Illinois, pp. 252-258.

11. Baumann HA, Morrison L, Stengel DB (2009) Metal accumulation and toxicity measured by PAMchlorophyll fluorescence in seven species of marine macroalgae. Ecotoxicol Environ Saf 72, 10631075.

12. Björkman O, Demming B (1987) Photon yield of oxygen evolution and chlorophyll fluorescence characteristics at $77 \mathrm{~K}$ among vascular plants of diverse origin. Planta 170, 489-504.

13. Chaves MM, Flexas J, Pinheiro C (2009) Photosynthesis under drought and salt stress: regulation mechanisms from whole plant to cell. Ann Bot 103, 551-560.

14. Chugh LK, Sawhney SK (1999) Photosynthetic activities of Pisum sativum seedlings grown in presence of cadmium. PI Physiol Biochem 37, 297-303.

15. Chugh KS, Singhal PC, Sharma BK (1975) Methanoglobinemia in acute copper sulphate poisoning. Ann Internal Med. 82, 226-229. 
16. Cui YJ, Zhu YG, Zhai RH, Chen DY, Huang YZ, Qiu Y, Liang JZ (2004) Transfer of metals from soil to vegetables in an area near a smelter in Nanning, China. Environ Int 30, 785-791.

17. Farooq M, Anwar F, Rashid U (2008) Appraisal of heavy metal content in different vegetables grown in the vicinity of an industrial area. Pak J Bot 40, 2099-2106.

18. Gaur A, Adholeya A (2004) Prospects of arbuscular mycorrhizal fungi in phytoremediation of heavy metal contaminated soils. Curr Sci 86, 528-534.

19. Gomez KA, Gomez AAS (1984) Statistical Procedures for Agricultural Research. Wiley, New York.

20. Gull J, Sultana B, Anwar F, Naseer R, Ashraf M, Ashrafuzzaman M (2012) Variation in antioxidant attributes at three ripening stages of guava (Psidium guajava L.) fruit from different geographical regions of Pakistan. Molecules 17, 3165-3180.

21. Gupta GK, Chahal J, Arora D (2011) Psidium guajava Linn: Current research and future prospects. J Pharm Res 1, 42-46.

22. Hassanein RA, Hashem HA, El-Deep HM, Shouman A (2013) Soil contamination with heavy metals and its effect on growth, yield and physiological responses of vegetable crop plants (turnip and lettuce). J Stress Physiol Biochem 9, 145-162.

23. Hattab S, Dridi B, Chouba L, Kheder MB, Bousetta H (2009) Photosynthesis and growth responses of pea Pisum sativum L. under heavy metals stress. J Environ Sci 21, 1552-1556.

24. Ikemoto Y, Teraguchi M, Kogayashi Y (2002) Plasma level of nitrate in congenital heart disease: comparison with healthy children. Pediatr Cardiol 23, 132-136.

25. Javaid S, Shah SGS, Chaudhary AJ, Khan MH (2008) Assessment of trace metal contamination of drinking water in the pearl valley, Azad Jammu and Kashmir. Clean-Soil, Air, Water. 36, 216-221.

26. Kaushik N, Kaur BP, Rao PS, Mishra HN (2013) Effect of high pressure processing on color, biochemical and microbiological characteristics of mango pulp (Mangifera indica cv. Amrapali). Innov Food Sci Emerg Technol 22, 40-50.

27. Khalid MF, Hussain S, Anjum MA, Ahmad S, Ejaz S, Ali MA, Saqib M (2017) Physico-chemical profiling of promising cultivars of litchi (Litchi chinensis Sonn.) fruit grown under agro-climatic conditions of Multan. Sci. Technol Develop 36, 183-188.

28. Lee HS, Castle WS (2001) Seasonal changes of carotenoid pigments and color in hamlin, early gold, and budd blood orange juices. J Agric Food Chem 49, 877-882.

29. Lone MI, Saleem S, Mahmood T, Saifullah K, Hussain G (2003) Heavy metal contents of vegetables irrigated by sewage/tubewell water. Inter J Agric Biol 5, 533-535.

30. Luo C, Liu C, Wang Y, Liu X, Li F, Zhang G, Li X (2011) Heavy metal contamination in soils and vegetables near an e-waste processing site, south China. J Hazard Mater 186. 481-490.

31. Mehmood A, Jafar M, Khan IA, Ahmad S (2018) Genetic diversity of Pakistani guava (Psidium guajava L.) germplasm and its implications for conservation and breeding. Sci Hort 172, $221-232$.

32. Menzel CM (1985) Guava: An exotic fruit with potential in Queensland. Queensland Agr J 111, 93-98. 
33. Myśliwa-Kurdziel B, Prasad MNV, Strzałka K (2002) Heavy metal influence on the light Phase of photosynthesis. In: Prasad M.N.V., Strzałka K. (Eds.), Physiology and Biochemistry of Metal Toxicity and Tolerance in Plants. Springer, Dordrecht, pp. 229-255.

34. Nicoli MC, Anese M, Parpine M (1999) Influence of processing on the antioxidant properties of fruit and vegetables. Trends Food Sci Technol 10, 94-100.

35. Oliver M (1997) Soil and human health: a review. Eur J Soil Sci 48, 573-592.

36. Othman OC, Mbogo GP (2009) Physico-chemical characteristics of storage ripened mango (Mangifera indica L.) fruit varieties of Eastern Tanzania. Tanz J Sci 35, 57-66.

37. Ouyang H, Kong X, He W, Qin, N, He Q, Wang Y, Wang R, Xu F (2012) Effects of five heavy metals at sub-lethal concentrations on the growth and photosynthesis of Chlorella vulgaris. Chi Sci Bull 57, 3363-3370.

38. Ozores-hampton M, Stansly PA, Obreza TA (2005) Heavy metal accumulation in a sandy soil and in pepper fruit following long-term application of organic amendments. Compost Sci Util 13, 60-64.

39. Pathak A, Dastidar MG, Sreekrishnan TR (2009) Bioleaching of heavy metals from sewage sludge: A review. J Environ Manag 90, 2343-2353.

40. Priya PG, Bashab CA, Ramamurthi V, Begum SN (2009) Recovery and reuse of Ni (II) from rinsewater of electroplating industries, J Hazard Mater 163, 899-909.

41. Radwan MA, Salama AK (2006) Market basket survey for some heavy metals in Egyptian fruits and vegetables. Food Chem Toxicol 44, 1273-1278.

42. Rahaman A, Afroza JS, Bashar K, Ali MdF, Hosen MdR (2016) A comparative study of heavy metal concentration in different layers of tannery vicinity soil and near agricultural soil. Ame $\mathrm{J}$ Anal Chem 7, 880-889.

43. Ruck J (1963) Chemical methods for analysis of fruit and vegetable products. Department of Agriculture, Research Station Summerland, Canada. Publication No. 1154, pp. 15-16.

44. Sharma RK, Agarwal M, Marshal FM (2006) Heavy metal contamination in vegetables grown in wastewater irrigated areas of Varanasi, India. The Bull Environ Contamin Toxicol 77, 311-318.

45. Sharma RK, Agarwal M, Marshal FM (2007) Heavy metal contamination of soils and vegetables in Suburban areas of Varanasi, India. Ecotoxicol Environ Safety, 66: 258-263.

46. Singh KP, Mohan D, Sinha S, Dalwan R (2004) Impact assessment of treated / untreated wastewater toxicants discharged by sewage treatment plants on health, agricultural and environmental quality in wastewater disposal area. Chemosphere 55, 227-255.

47. Souri MK, Hatamian M, Tesfamariam T (2019) Plant growth stage influences heavy metal accumulation in leafy vegetables of garden cress and sweet basil. Chem Biol Technol Agric 6 , .https://doi.org/10.1186/s40538-019-0170-3.

48. Wargovich MJ (2000) Anticancer properties of fruits and vegetables. HortSci 35, 573-575.

49. Wilson L (2011) Toxic metals and human health. The Center for Development. www.http://drlwilson.com/index.htm (accessed on: 14th December, 2011). 
50. Wolnik KA, Fricke FL, Capar SG, Braude GL, Meyer MW, Satzger RD, Bonnin E (1983) Elements in major raw agricultural crops in the United States. 1. Cadmium and lead in lettuce, peanuts, potatoes, soybeans, sweet corn and wheat. J Agric Food Chem 31, 1240-1244.

51. Zahoor A, Zahoor M (2003) Elemental distribution in summer fruits of Pakistan. Nutr Food Sci 33, 203-207.

\section{Figures}




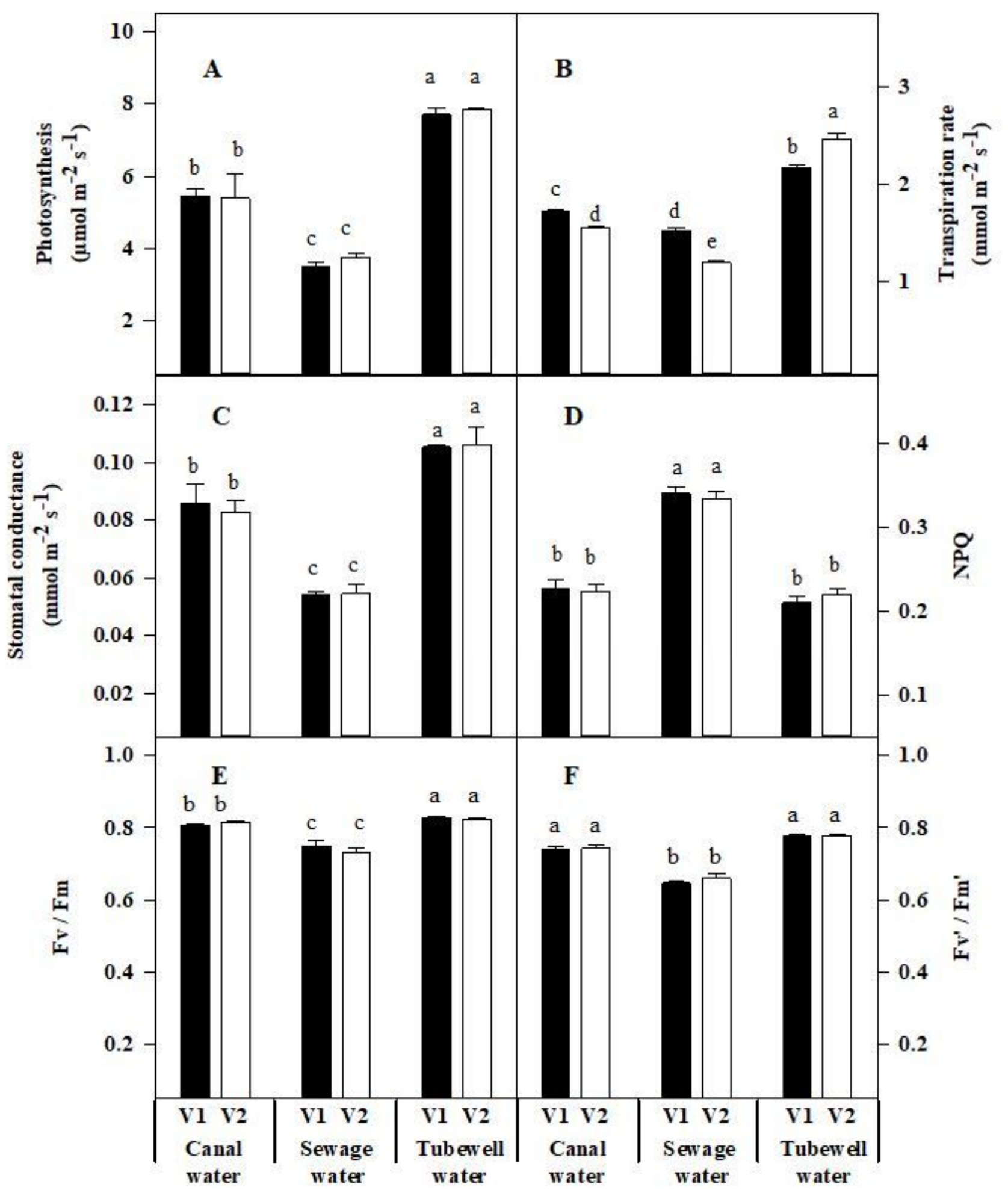

Figure 1

Different physiological attributes of Guava leaves (A) Photosynthesis; (B) Transpiration rate; (C) Stomatal conductance; (D) Non Photochemical Quenching; (E) leaf chlorophyll fluorescence in dark-acclimated $(\mathrm{Fv} / \mathrm{Fm}) ;(\mathrm{F})$ leaves leaf chlorophyll fluorescence in light $\left(\mathrm{Fv}^{\prime} / \mathrm{Fm}^{\prime}\right)$. Values are mean \pm S.E. at $\mathrm{p}<0.05(\mathrm{n}=$ 3). V1= Gola and V2= Surahi. 